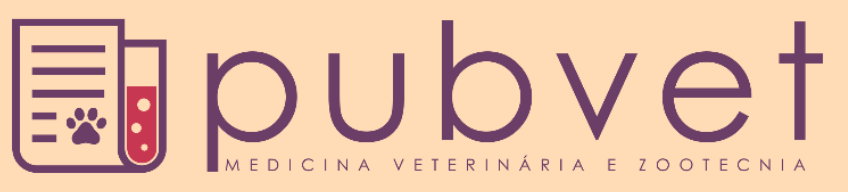

https://doi.org/10.31533/pubvet.v15n09a913.1-7

\title{
Influence of environmental tobacco smoke on the etiology of lymphoma in domestic cats
}

\author{
Mariana Luquetti Gervásio $^{1} \bullet$, Mariana Almeida ${ }^{1}$, Bianca Desordi Lima ${ }^{2}$, Cláudia Sampaio \\ Fonseca Repetti ${ }^{3 *} \bullet$ \\ ${ }^{1}$ Médica veterinária, graduada pela Universidade de Marília, Marília, São Paulo, Brasil \\ ${ }^{2}$ Médica veterinária, aprimoranda em Clínica Cirúrgica de Pequenos Animais da Universidade de Marília, São Paulo, Brasil \\ ${ }^{3}$ Médica veterinária, docente do curso de Medicina Veterinária da Universidade de Marília, Marília, São Paulo, Brasil \\ *Autor para correspondência, E-mail: claudiarepetti@yahoo.com.br
}

\begin{abstract}
Neoplasms correspond to the large part of routine care of domestic animals, and, among them, lymphoma represents the tumor with the highest incidence in domestic cats. Due to its multifactorial etiology, being influenced by environmental factors and lifestyles of the animals, we raised the hypothesis that exposure to tobacco smoke influences the development of lymphoma in domestic cats. These animals are very close to the guardians, in addition to hygiene habits (grooming), which favors the inhalation of smoke and ingestion of tobacco particles that are deposited in the fur. According to studies, domestic cats exposed to tobacco smoke have higher risks of developing lymphoma when compared to non-exposed cats, and this higher index is directly related to the components found in smoke. Nicotine, cotinine and NNAL(4-(methylnitrosamine)-1-(3-pyridil)-1-butanone) are the main metabolites derived from tobacco and they have been used as urinary biomarkers. Studies show that domestic cats that live in households with the presence of smokers present relevant levels of urinary biomarkers when compared to animals not exposed to environments with smokers. Nicotine levels in animals are directly proportional to the number of cigarettes smoked by guardians and are related to the degree of exposure of animals. Based on epidemiological research, exposure to smoke is related to the emergence of neoplasms in domestic cats similar to that in humans, but it is necessary to develop new research in the veterinary area.
\end{abstract}

Keywords: Feline, lymphoma, neoplasia, nicotine, smoke

\section{Influência da fumaça do cigarro na etiologia do linfoma em gatos domésticos}

Resumo. As neoplasias correspondem à grande parte do atendimento de rotina dos animais domésticos, e, dentre elas, o linfoma representa o tumor de maior incidência em felinos. Devido à sua etiologia multifatorial, sendo influenciada por fatores ambientais e estilos de vida dos animais, levantou-se a hipótese de a exposição à fumaça do cigarro exercer influência no desenvolvimento do linfoma em felinos. Estes animais possuem grande proximidade com os tutores, além de hábitos de higiene (grooming), o que favorece a inalação da fumaça e ingestão de partículas do tabaco que se depositam no pelo. Segundo estudos, felinos expostos à fumaça do tabaco apresentam riscos maiores de desenvolverem linfoma quando comparados a gatos não expostos, e esse maior índice relaciona-se diretamente aos componentes encontrados na fumaça. Sendo a nicotina, cotinina e NNAL (4-(metilnitrosamina)-1-(3-piridil)-1-butanona) os principais metabolitos derivados do tabaco que vem sendo utilizados como biomarcadores urinários. Estudos demonstram que felinos que habitam domicílios com presença de fumantes, apresentam níveis relevantes de 
biomarcadores urinários quando comparados a animais não expostos a ambientes com fumantes. Os níveis de nicotina nos animais são diretamente proporcionais ao número de cigarros fumados pelos tutores, estando relacionado ao grau de exposição dos animais. Com bases em pesquisas epidemiológicas relaciona-se a exposição à fumaça com o aparecimento de neoplasias em felinos semelhante a que ocorre em humanos, porém é necessário o desenvolvimento de novas pesquisas na área veterinária.

Palavras-chave: Felino, fumaça, linfoma, neoplasia, nicotina

\section{Influencia del humo del cigarrillo en la etiología del linfoma en gatos domésticos}

Resumen. Las neoplasias corresponden a gran parte del atendimiento rutinario de los animales domésticos y, entre ellas, el linfoma representa el tumor con mayor incidencia en felinos. Debido a su etiología multifactorial, al estar influenciada por factores ambientales y estilos de vida de los animales, se planteó la hipótesis de que la exposición al humo del cigarrillo influye en el desarrollo del linfoma en felinos. Estos animales tienen una gran proximidad con los tutores, además de los hábitos de higiene (acicalamiento), lo que favorece la inhalación de humo y la ingestión de partículas de tabaco que se depositan en el pelo. Según estudios, los felinos expuestos al humo del tabaco tienen un mayor riesgo de desarrollar linfoma en comparación con los gatos no expuestos, y este índice más alto está directamente relacionado con los componentes que se encuentran en el humo. Nicotina, cotinina y NNAL (4- (metilnitrosamina) - 1 - (3-piridil) -1-butanona) son los principales metabolitos derivados del tabaco y se han utilizado como biomarcadores urinarios. Los estudios muestran que los felinos que viven en hogares con fumadores presentan niveles relevantes de biomarcadores urinarios en comparación con los animales no expuestos a ambientes con fumadores. Los niveles de nicotina en los animales son directamente proporcionales al número de cigarrillos fumados por los guardianes, estando relacionado con el grado de exposición de los animales. Con base en investigaciones epidemiológicas, la exposición al humo se relaciona con la aparición de neoplasias en gatos similar a lo que ocurre en humanos, sin embargo, es necesario desarrollar nuevas investigaciones en el área veterinaria.

Palabras clave: Felino, humo, linfoma, neoplasia, nicotina

\section{Introduction}

Currently, cancer is the leading cause of death in companion animals, accounting for $32 \%$ of deaths in domestic cats. On the other hand, lymphoma is the most diagnosed neoplasm among these animals, corresponding to one third of the tumors in this species and $90 \%$ of all hematopoietic neoplasms of domestic cats. It begins in lymphoid tissue and may involve any organ or tissue (Withrow et al., 2020).

Lymphoma is of multifactorial etiology, since several factors may influence its emergence, being generally related to feline leukemia virus and feline immunodeficiency virus, since most animals with lymphoma test positive for the viruses described above (Cotter et al., 1975; Withrow et al., 2020). However, the increased frequency of vaccination of these animals against feline leukemia has reduced the prevalence of this infection in domestic cats, and the proportion of animals with lymphoma and concomitant infection by feline leukemia virus have decreased substantially.

The therapeutic options for lymphoma in domestic cats include chemotherapy, indicated for systemic disease, in addition to surgery and radiotherapy (associated or not with chemotherapy), for isolated cases (Daleck et al., 2016; Sorenmo, 2003; Vail \& Ogilvie, 2003).

The main objective of chemotherapy is to improve quality of life and prolong the survival time of patients with lymphoma (Vail \& Ogilvie, 2003). Chemotherapy is based on three steps: induction, maintenance and reinduction of remission or rescue therapy. High doses are administered during induction with shorter intervals between chemotherapy preparations. After remission, the maintenance phase begins, in which the doses used are lower and the interval between the sessions is longer, whose 
objective is to maintain the clinical remission of the disease. Finally, rescue therapy is the attempt of remission in a second or third time, using a more aggressive course of chemotherapy (Daleck et al., 2016). Chemotherapy drugs commonly used in the various protocols include doxorubicin, cyclophosphamide, methotrexate, L-asparaginase, lomustine, vincristine and chlorambucil (Vail, 2007).

Animals that do not receive treatment die in a period of four to six weeks, although in cats in which polychemotherapy is made, an average survival of five to seven months is observed (Stell \& Dobson, 2006; Vail \& Ogilvie, 2003). This fact occurs due to the low rate of remission of the disease in the feline species (50 to 70\%), but those that manage to obtain complete remission reach a survival of up to two years. Cures are still unusual (Stell \& Dobson, 2006).

The initial response to chemotherapy is the most effective prognostic factor for domestic cats. Thus, animals that possess complete remission have a longer survival than those that had partial remission. In addition, the anatomical location of lymphoma is also an important prognostic factor, because those animals with involvement of nasal lymphoma or peripheral lymph nodes have longer survival time when compared to those whose lymphoma is in the kidneys or nervous system. According to the WHO, the more advanced the neoplasm, with systemic involvement, the worse the prognosis (Morris \& Dobson, 2001).

\section{Influence of tobacco smoke on lymphoma induction}

The feline leukemia virus, each time, has been playing a smaller role in the etiology of lymphoma in this species, what raised some questions, by researchers, about the possible influence of environmental factors and lifestyle on the risk of developing the disease in cats, as occurs in humans (Bertone et al., 2002). The effects of secondhand smoke on health among humans are well known, whereas the analysis of epidemiological data suggests that the exposure of companion animals to tobacco smoke may be associated with the development of certain malignant neoplasms, including lymphoma and squamous cell carcinoma in domestic cats (Bertone et al., 2002; Smith et al., 2020), nose tumors (Reif et al., 1998) and lung carcinomas in dogs (Reif et al., 1992).

By sharing the same living environment with humans, domestic cats are exposed to many of the same environmental contaminants as their guardians, including exposure to tobacco smoke in the environment (Bukowski \& Wartenberg, 1997). Furthermore, the proximity relationship with the guardians facilitates the absorption of smoke constituents by contact with contaminated clothing and skin (Smith et al., 2017). Bertone et al. (2002) reported that domestic cats exposed to tobacco smoke have a significantly higher risk of developing lymphoma when compared to those living in non-smoking environments. These authors observed that this risk is directly associated with the duration and amount of exposure to this smoke. Thus, animals that had been exposed to smoke for more than five years and those living in households where one or more cigarette packs were smoked per day, had a significant increase of three times in the risk of developing this tumor compared to animals without family exposure. This was the first study to correlate household exposure to tobacco smoke and the risk of lymphoma in cats or other domestic animals.

Although no clear mechanism has been proposed to explain the association between active smoking or secondhand smoking and the development of non-Hodgkin lymphoma in humans, we believe that several tobacco components can be carcinogenic to lymphoid tissue and cause mutation in lymphocyte precursors (Adami et al., 1998). More than 40 mutagenic agents and carcinogens existing in inhaled cigarette smoke have been identified, many of which have been implicated in human carcinogenesis (Husgafvel-Pursiainen et al., 2000; Romano et al., 1997).

The routes of exposure of companion animals to the components of tobacco smoke are through inhalation of smoke in the air, transdermal absorption of particles and residues that can be concentrated in the fur and skin after contact with carpets, furniture, bedding and the ingestion of particles deposited in the skin during sanitization (Bukowski \& Wartenberg, 1997). Especially cats, as they have the habit of licking themselves when performing grooming, becoming one of the main sources of exposure (Bukowski \& Wartenberg, 1997; Smith et al., 2020). In vitro studies using human tissues have shown that tobacco smoke has a direct carcinogenic effect on mucosa gastric cells (Tayler \& Piper, 1977). 
Similarly, Smith et al. (2020) reported that the ingestion of toxins and carcinogens present in tobacco ambient smoke increase the likelihood of developing gastrointestinal lymphoma in cats.

It has been reported that domestic cats exposed to tobacco smoke have an increased expression of the oncogenic P53 gene, one of those responsible for the increased risk of lymphoma (Bertone-Johnson et al., 2008). According to Daleck et al. (2016), this is one of the tumor suppressor genes, responsible for negatively regulating cell growth and when mutated they lose their function leading to uncontrolled growth, being the most often mutated in neoplasms.

Previous studies were conducted using questionnaires with the guardians of domestic cats, investigating the relationship between exposure to tobacco smoke and the occurrence of neoplasms (Bertone-Johnson et al., 2008; Snyder et al., 2004). Although they are low cost and easy to perform, it is often necessary to trust that owners are being true in their answers, in addition to not being able to quantify the exposure to tobacco smoke (Smith et al., 2017).

Biomarkers have been used to make a biological monitoring about exposure to certain chemical agents in order to quantify the researched substance or even its metabolites, in biological environment such as saliva, blood, urine, among others. Thus, tobacco biomarkers can be used to measure systemic exposure to cigarette constituents by smokers or nonsmokers (Amorim, 2003; Barros, 2016). Urinary biomarkers of tobacco include nicotine, cotinine and 4-(methylnitrosamino)-1-(3-pyridil)-1-butanol (NNAL) and have been widely used in the assessments of human populations, including smokers, nonsmokers and people exposed to tobacco smoke (Hukkanen et al., 2005).

As humans, cats exposed to domestic tobacco smoke metabolize nicotine in cotinine and demonstrate urinary cotinine concentrations that increase the higher the exposure (Bertone-Johnson et al., 2008). Such urinary biomarkers provide information about exposure but are not carcinogenic. Nitrosamines are also derived from nicotine and are found in tobacco smoke, and NNAL (4-(methylnitrosamine)-1(3-pyridil)-1-butanone) is the main carcinogenic metabolite, thus being useful in the study of diseases associated with smoke inhalation (McNiel et al., 2007). Despite of urinary cotinine (a metabolite of nicotine) is increased in cats from smoking households (McNiel et al., 2007), its half-life is only 10 to 14 hours, and therefore, as a biomarker, it reflects only recent exposure to tobacco smoke, not being useful for long-term exposure studies (Eliopoulos et al., 1996). Nicotine is the main constituent of tobacco smoke and is used as a biomarker. Such a metabolite can be absorbed directly from the environment by the fur and by systemic circulation when smoke is absorbed by the body (Al-Delaimy, 2002).

McNiel et al. (2007) measured urinary biomarker levels in domestic cats exposed to environmental tobacco smoke. A total of 19 animals from the households in which there were smokers were selected, and after collecting urine, the levels of nicotine, cotinine and NNAL were measured. The researchers observed that the values of these biomarkers were high compared to animals that inhabited non-smoking households. They also reported that eight of the 19 animals had undetectable urinary levels of NNAL, suggesting that there is a relationship between exposure to ambient tobacco smoke with NNAL levels, i.e., those animals with undetectable urinary concentrations of NNAL had lower exposure to smoke than cats with measurable urinary concentrations of NNAL.

In humans, the measurement of nicotine concentration in hair is well related to exposure to tobacco smoke (Al-Delaimy, 2002), while in dogs, they have shown a positive association with the exposure reported by guardians (Knottenbelt et al., 2012).

Studies conducted by Smith et al. (2017) demonstrated the presence of constituents of tobacco smoke in the pets' fur exposed to internal environments with smokers. This group of researchers demonstrated that the level of nicotine in fur was higher in cats exposed when compared to animals not exposed to tobacco smoke, allowing nicotine in the fur to be used as a biomarker in these animals. This level of nicotine was positively associated with the number of cigarettes smoked daily by the owners, similar to the reports in humans (Nafstad et al., 1995; Okoli et al., 2007; Tzatzarakis et al., 2012).

Although inhalation may be the main route of exposure to tobacco ambient smoke in cats, we speculate that their meticulous hygiene behavior, due to their constant habit of licking, may lead to 
increased exposure to carcinogen through the oral route. Nicotine is found in hair and domestic surfaces, both of which can serve as a source of exposure for pets (Matt et al., 2004; Smith et al., 2017).

When comparing the nicotine levels found in cat's fur with that described in the literature in dogs exposed to tobacco ambient smoke, Smith et al. (2017) observed that the values found in cats were higher. One hypothesis for these values is the licking habit of cats, which could result in higher nicotine ingestion, later deposited in the fur nail through systemic circulation (Al-Delaimy, 2002), associated with a more intimate contact with guardians than dogs.

However, Smith et al. (2020) analyzed nicotine biomarkers in cat's fur in order to investigate the association between exposure to tobacco smoke and gastrointestinal lymphoma, using sick animals and healthy animals, and unlike other researchers (Bertone et al., 2002), they did not find differences between the two groups of animals, justifying the need for further research. In a recent study, the authors demonstrated that nicotine values $\geq 0.1 \mathrm{ng} / \mathrm{mg}$ in cat's fur, suggest that they had exposure to environmental tobacco smoke, with specificity of $98 \%$ and sensitivity of 69\% (Smith et al., 2017).

Thus, we understand that carcinogenesis is a complex and multifactorial process, which involves genetic mutations, including the activation of oncogenes and the inactivation of tumor suppressor genes, leading to a loss of normal cellular homeotase. Many environmental and genetic factors, including exposure to tobacco smoke and chronic inflammation of the mucosa may therefore play a role in the development of gastrointestinal lymphoma. The number of interaction factors involved and the prolonged time during which the accumulation of mutations makes it more difficult to identify risk factors, so more studies using biomarkers of exposure to tobacco smoke in cats are necessary ( $\underline{\text { Smith et }}$ al., 2020).

Based on epidemiological information, we assume that exposure to cigarette smoke is related to the appearance of certain neoplasms in cats similar to what occurs in humans (Bertone et al., 2002); however, additional research is needed (Mcniel et al., 2007).

\section{Final considerations}

Given the above, we conclude that exposure to chemical carcinogens present in tobacco smoke may constitute a risk factor for the development of lymphoma in domestic cats. However, further research is needed to establish a greater cause-and-effect relationship, so that prevention and early diagnosis measures can be delineated for this type of tumor in domestic cats.

\section{References}

Adami, J., Nyrén, O., Bergström, R., Ekbom, A., Engholm, G., Englund, A., \& Glimelius, B. (1998). Smoking and the risk of leukemia, lymphoma, and multiple myeloma (Sweden). Cancer Causes \& Control, 9(1), 49-56. https://doi.org/10.1023/a:1008897203337.

Al-Delaimy, W. K. (2002). Hair as a biomarker for exposure to tobacco smoke. Tobacco Control, 11(3), 176-182. https://doi.org//10.1136/tc.11.3.176.

Amorim, L. C. A. (2003). Os biomarcadores e sua aplicação na avaliação da exposição aos agentes químicos ambientais. Revista Brasileira de Epidemiologia, 6, 158-170. https://doi.org/10.1590/S1415-790X2003000200009.

Barros, R. (2016). Biological markers of smoking. Journal of Medical and Biological Sciences, 15(1), $110-116$.

Bertone-Johnson, E. R., Procter-Gray, E., Gollenberg, A. L., Ryan, M. B., \& Barber, L. G. (2008). Environmental tobacco smoke and canine urinary cotinine level. Environmental Research, 106(3), 361-364. https://doi.org/10.1016/j.envres.2007.09.007.

Bertone, E. R., Snyder, L. A., \& Moore, A. S. (2002). Environmental tobacco smoke and risk of malignant lymphoma in pet cats. American Journal of Epidemiology, 156(3), 268-273. https://doi.org/10.1093/aje/kwf044..

Bukowski, J. A., \& Wartenberg, D. (1997). An alternative approach for investigating the carcinogenicity of indoor air pollution: pets as sentinels of environmental cancer risk. Environmental Health Perspectives, 105(12), 1312-1319. https://doi.org/10.1289/ehp.971051312. 
Cotter, S. M., Hardy Junior, W. D., \& Essex, M. (1975). Association of feline leukemia virus with lymphosarcoma and other disorders in the cat. Journal of the American Veterinary Medical Association, 166(5), 449-454.

Daleck, C. R., Fonseca, C. S., \& Canola, J. C. (2016). Oncologia em cães e gatos. Roca.

Eliopoulos, C., Klein, J., \& Koren, G. (1996). Validation of self-reported smoking by analysis of hair for nicotine and cotinine. Therapeutic Drug Monitoring, 18(5), 532-536. https://doi.org/10.1097/00007691-199610000-00002.

Hukkanen, J., Jacob, P., \& Bennowitz, N. L. (2005). Metabolism: Clinical and Experimental and disposition kinetics of nicotine. Pharmacological Reviews, 57, 79-115. https://doi.org/10.1124/pr.57.1.3.

Husgafvel-Pursiainen, K., Boffetta, P., Kannio, A., Nyberg, F., Pershagen, G., Mukeria, A., Constantinescu, V., Fortes, C., \& Benhamou, S. (2000). p53 mutations and exposure to environmental tobacco smoke in a multicenter study on lung cancer. Cancer Research, 60(11), 2906-2911.

Knottenbelt, C. M., Bawazeer, S., Hammond, J., Mellor, D., \& Watson, D. G. (2012). Nicotine hair concentrations in dogs exposed to environmental tobacco smoke: a pilot study. Journal of Small Animal Practice, 53(11), 623-626. https://doi.org/10.1111/j.1748-5827.2012.01284.x.

Matt, G. E., Quintana, P. J. E., Hovell, M. F., Bernert, J. T., Song, S., Novianti, N., Juarez, T., Floro, J., Gehrman, C., \& Garcia, M. (2004). Households contaminated by environmental tobacco smoke: sources of infant exposures. Tobacco Control, 13(1), 29-37. https://doi.org/10.1136/tc.2003.003889.

McNiel, E. A., Carmella, S. G., Heath, L. A., Bliss, R. L., Le, K.-A., \& Hecht, S. S. (2007). Urinary biomarkers to assess exposure of cats to environmental tobacco smoke. American Journal of Veterinary Research, 68(4), 349-353. https://doi.org/10.2460/ajvr.68.4.349.

Morris, J., \& Dobson, J. M. (2001). Small animal oncology. Wiley Online Library.

Nafstad, P., Botten, G., Hagen, J. A., Zahlsen, KNilsen, O. G., Silsand, T., \& Kongerud, J. (1995). Comparison of three methods for estimating environmental tobacco smoke exposure among children aged between 12 and 36 months. International Journal of Epidemiology, 24(1), 88-94. https://doi.org/10.1093/ije/24.1.88.

Okoli, C. T. C., Hall, L. A., Rayens, M. K., \& Hahn, E. J. (2007). Measuring tobacco smoke exposure among smoking and nonsmoking bar and restaurant workers. Biological Research for Nursing, 9(1), 81-89. https://doi.org/10.1177/1099800407300852.

Reif, J. S., Bruns, C., \& Lower, K. S. (1998). Cancer of the nasal cavity and paranasal sinuses and exposure to environmental tobacco smoke in pet dogs. American Journal of Epidemiology, 147(5), 488-492. https://doi.org/10.1093/oxfordjournals.aje.a009475.

Reif, J. S., Dunn, K., Ogilvie, G. K., \& Harris, C. K. (1992). Passive smoking and canine lung cancer risk. American Journal of Epidemiology, 135(3), 234-239. https://doi.org/10.1093/oxfordjournals.aje.a116276.

Romano, G., Mancini, R., Fedele, P., Curigliano, G., Flamini, G., Giovagnoli, M. R., Malara, N., Boninsegna, A., Vecchione, A., \& Santella, R. M. (1997). Immunohistochemical analysis of 4aminobiphenyl-DNA adducts in oral mucosal cells of smokers and nonsmokers. Anticancer Research, 17(4A), 2827-2830. https://doi.org/.

Smith, V. A., McBrearty, A. R., Watson, D. G., Mellor, D. J., Spence, S., \& Knottenbelt, C. (2017). Hair nicotine concentration measurement in cats and its relationship to owner-reported environmental tobacco smoke exposure. Journal of Small Animal Practice, 58(1), 3-9. https://doi.org/10.1111/jsap.12616.

Smith, V., Knottenbelt, C., Watson, D., Mellor, D. J., Guillen Martinez, A., Philp, H., Keegan, S., Marrington, M., Giannasi, C., \& Cave, T. (2020). Hair nicotine concentration of cats with gastrointestinal lymphoma and unaffected control cases. Veterinary Record, 186(13), 414. https://doi.org/10.1136/vr.105564.

Snyder, L. A., Bertone, E. R., Jakowski, R. M., Dooner, M. S., Jennings-Ritchie, J., \& Moore, A. S. (2004). p53 expression and environmental tobacco smoke exposure in feline oral squamous cell carcinoma. Veterinary Pathology, 41(3), 209-214. https://doi.org/10.1354/vp.41-3-209. 
Sorenmo, K. (2003). Canine mammary gland tumors. Veterinary Clinics of North America: Small Animal Practice, 33(3), 573-596.

Stell, A., \& Dobson, J. M. (2006). Chemotherapy in the treatment of neoplasms. In E. A. Chandler, C. J. Gaskell, \& R. M. Gaskell (Eds.), Clínica e terapêutica de felinos. Roca, Brasil.

Tayler, R., \& Piper, D. W. (1977). The carcinogenic effect of cigarette smoke: The effect of cigarette smoke on human gastric mucosal cells in organ culture. Cancer, 39(6), 2520-2523. https://doi.org/10.1002/1097-0142(197706)39:6<2520::AID-CNCR2820390632>3.0.CO;2-C.

Tzatzarakis, M. N., Vardavas, C. I., Terzi, I., Kavalakis, M., Kokkinakis, M., Liesivuori, J., \& Tsatsakis, A. M. (2012). Hair nicotine/cotinine concentrations as a method of monitoring exposure to tobacco smoke among infants and adults. Human \& Experimental Toxicology, 31(3), 258-265. https://doi.org/10.1177/0960327111422401.

Vail, D. M. (2007). Feline lymphoma and lymphoid leukemis. In S. J. Withrow \& E. G. MacEwen (Eds.), Small animal clinical oncology (pp. 733-752). Sauders Elsevier.

Vail, D. M. E., \& Ogilvie, G. K. (2003). Neoplasias linfoides. In S. J. Bichard \& R. G. Sherding (Eds.), Manual Saunders: Clínica de Pequenos Animais (pp. 227-233). Roca.

Withrow, Stephen J, Page, R., \& Vail, D. M. (2020). Small animal clinical oncology. Elsevier Health Sciences. https://doi.org/10.1201/9781315381855.

Article History:

Received: March 16, 2021

Accepted: April 29,2021
License information: This is an open-access article distributed under the terms of the Creative Commons Attribution License 4.0, which permits unrestricted use, distribution, and reproduction in any medium, provided the original work is properly cited. 